\title{
ARCHITECTURAL RENOVATION USING TRADITIONAL TECHNOLOGIES, LOCAL MATERIALS AND ARTISAN'S LABOR IN CATALONIA.
}

\author{
O. Roselló ${ }^{1, *}$ \\ ${ }^{1}$ Architect Founder of www.bangolo.com and member co-founder of www.projectegreta.cat \\ C.Pau Claris 154 Planta 4 Barcelona 08009 - loriol@ coac.net
}

Commission II - WG II/8

KEY WORDS: Masia, Artisans, Vernacular, Architectural refurbish, Traditional technologies.

\begin{abstract}
:
The use of traditional techniques when restoring a masia is always the primary consideration in the preliminary phase of the project and during the site work. The virtues of traditional techniques compared to industrial production systems are described from multiple points of view: as a sustainable contemporary strategy, as generators of healthy spaces, as virtues of social and territorial scale, as a better formal contextualisation due to the limitations of pre-industrial materials. These are virtues that the industrial system has forgotten. The purpose of the Can Buch project (a masia in Northen Catalonia, Spain) was to restore the main house, some sheds and a barn, to enable rural ecotourism and to create a residence for the owner and future manager of the property. The promoter of the project intended to apply the values of permaculture. Maximising the use of $\mathrm{Km} 0$ materials from the start emphasised this intention. If we understand the traditional farmhouse as the site's resource map, applying this reality to the present work means recovering original representative principles. Currently, the project is in the last phase of works, but the results of applying this philosophy are already visible. It is intended to demonstrate the advantages of this self-limitation on a sustainable, environmental, territorial and compositional level.
\end{abstract}

\section{INTRODUCTION}

\subsection{The pre-existing architecture}

The country house, Can Buch is located in the La Barroca district, in the municipality of Sant Aniol de Finestres, in the NW of the Llémana valley, a region near Girona city, Catalonia, that still proudly keeps in part, a traditional agricultural landscape (Figure 1).

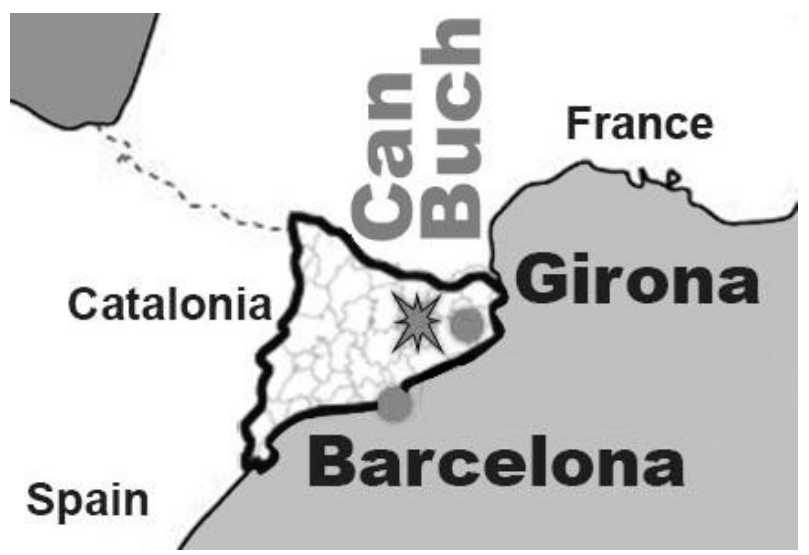

Figure 1. Can Buch location near Girona city.

The remains of the original building that we found on our first visit in autumn 2016 were nothing more than two ruined walls and demolition waste (Figure 2). From the very beginning, we realised that this "rehabilitation" project would be a brand new construction. In spite of this realisation, we could use some information from the building itself. We could still recognise the original footprint from the remaining traces, limited from the very beginning, by the geometry of the four façades and the different roof sides. By studying the ruins, we found the materials used in theoriginal building. Finally, it was possible to identify some possible construction systems to be used as an inspiration add to the new building.

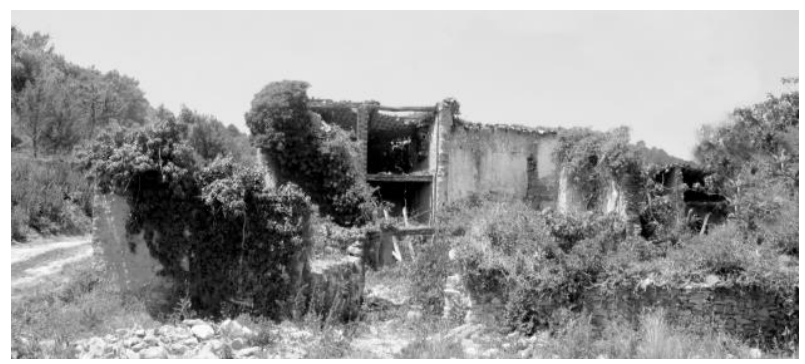

Figure 2. Can Buch as we first saw it in autumn 2016.

\subsection{The client's project}

Gerad Bofill, the young developer of this project, was searching for a country house like this in order to develop a very special rural hotel. With ractical experience on permaculture farming practice he wanted to implement those principles for his personal project. Permaculture is based on both, technical design and ethical patterns for a better environment, economy, technology, health and education (Holmgren, 2007).

He understood from the very beginning, that to restore the whole property, he should start with the forest management, recovering the fruits crops, the vegetable garden and stockbreeding. So, the architectural restoration was part of a general willingness to recover the traditional activity on the now untenanted territory. Definitely this project was both an architectural and a lifestyle project with an educational goal.

\footnotetext{
* Corresponding author
} 


\subsection{The local administration}

In Catalonia, there is strict urban regulation when dealing with an isolated farmhouse project. Sometimes this fact reinforces the current depopulation trend of dispersed rural areas. We had the firm support of the local administration. The mayor realized that this project was a clear example of how a younger generation can repopulate an area. In this valley, there is a great sense of local community. People are very concerned about the depopulation of rural areas and the abandonment of the agropastoral activity. The risk is of lack of activity rather than the pressure of over-population, "environmental deterioration results from both excess and withdrawal from human intervention" (Tello, 2006). This project has obtained financial aid from the European program LEADER to prevent the depopulation of dispersed rural areas. It is notable that both the local community and the administration responsible for the building permission, have welcomed this project.

\subsection{Our experience in architecture restoration}

We have experienced over the last 20 years a particular way of restoring anonymous architecture in the Girona area. From the experience and the knowledge we have shared with local artisans, we could define and establish a few principles to tackle any project.

Even when implementing a new language, working with traditional technologies guarantees an optimum contextualisation with the original building. (Alcindor, Roselló, 2013).

Self-limitation on using pre-industrial materials represents a way to recover traditional expertise. This is particularly significant when an increase of thermal characteristics on old walls is required.

Working with artisans has been a critical element in our procedures. When co-operating with artisans from the very beginning, it has been necessary to redefine the traditional role of the architect. We now share the creative process during design, the decision making during construction and the authorship once the project is complete.

Maximising the use of $0 \mathrm{Km}$ materials enhances, even more, the sustainability standards of this procedure. In some ways, it represents one of the chief advantages of traditional knowledge.

Based upon these four previous determinations is the uniqueness of this project. The material remains of the original farmhouse, the vision of the project developed by the owner, the strength of the local community in the area and the modus operandi of the architects.

\section{CAN BUCH RECOVERING}

\subsection{The architectural challenges of this proposal}

From the area of the original masia, we have reorganised the accommodation of the rural hotel brief and the owner's house. The owners house has been rebuilt in the little barn at the east. The rural hotel is concentrated in what was the the main building. Most of the bedroom and facilities were placed on the ground floor and on the upper floor the common areas such as kitchen, dining room and lounge space. All those rooms are connected with a central covered patio that works as a core space and main entrance. A part from interior accommodation, the following outdoor services and existing infrastructure helped to facilitate the general project in its intention of becoming self-sufficient: a reservoir for roof run-off rainwater, a natural sewage filtration system, a car pergola with photovoltaic panels, a vegetable filtration swimming pool and a shed for the biomass boiler (Figure 3).

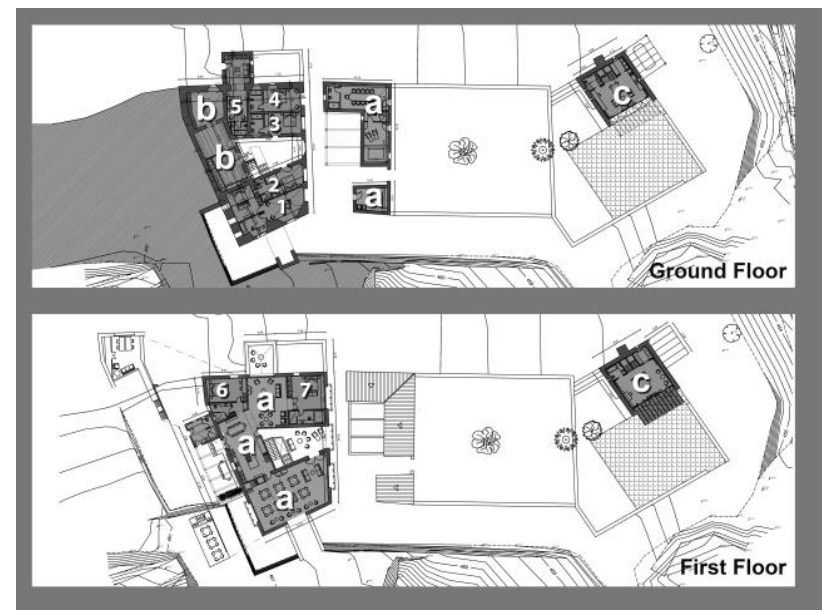

Figure 3. Can Buch rural hotel and dwelling distribution.

A: kitchen, living room and dining room; B: Machinery room and pantry; C: Owner's house

This rehabilitation project had a unique opportunity to deal with today's controversies on how to restore a masia. For one reason because this was almost a new construction project and, on the other hand, the owner who had no intention to mimic whatever the original Masia that Can Buch was previously. We all wanted to build with local materials, traditional techniques, and in collaboration with artisans, which were the same strategies used in the 20th century to build a masia. We can summarise the motivations that have led us to apply new concepts when rebuilding Can Buch in the following points:

- The need to increase thermal efficiency without losing its fundamental intrinsic thermal properties.

- To guarantee natural light and ventilation in every rural hotel room with a good ratio between apertures and mass of the resulting elevations.

- To enhance the fantastic views of the privileged environment, avoiding facades typical of modern architecture.

- To maximise the use of $0 \mathrm{Km}$ raw materials and self-limit to the use only of pre-industrial materials without giving up a contemporary language.

- To design constructive solutions that allow local artisans to transfer their knowledge and skills to the project.

\subsection{To adjust the thermal characteristics of a vernacular typology}

When a restoring a masia one of the main goals is to provide proper thermal comfort to meet today's requirements. In ancient times both the ground floor and the upper floor were not meant to be used as human dwelling spaces. Domestic comfort was only required on the main floor. In order to increase comfort, the architect has to deal with both ecoefficiency and heritage conservation. 
Unfortunately, in many cases, the solution is just adding some inner isolation plate and a finishing layer. When doing this we lose two advantage of the original building behaviour, on the one hand we gain insulation coefficient, but we lose the valuable thermal inertia of the stone walls, and on the other hand, we forgot about the hydrothermal control that the old lime clay renders can offer to the inner spaces.

Contemporary architecture usually only deals with insulation coefficients since following the oversimplification of the scientific method means missing other variables that are part of sophisticated thermal comfort (Prieto, 2019). These mistakes have increased in the last decades, starting with the "Passivhaus" certificate which might work for upper latitudes, but not in our climate.

We have chosen not to change the outside walls of the original building since they are part of the historical landscape. From inside we have applied an $8 \mathrm{~cm}$ layer of argyle (clay) mixed with hemp, straw and crushed reeds. The whole structure (even the ring beam) is made of solid wood, so no thermal bridge occurs. Whole doors and windows are designed with regular double glazing and have an inner wooden shutter that keeps the warm air inside during the cold winter nights (Figure 4).
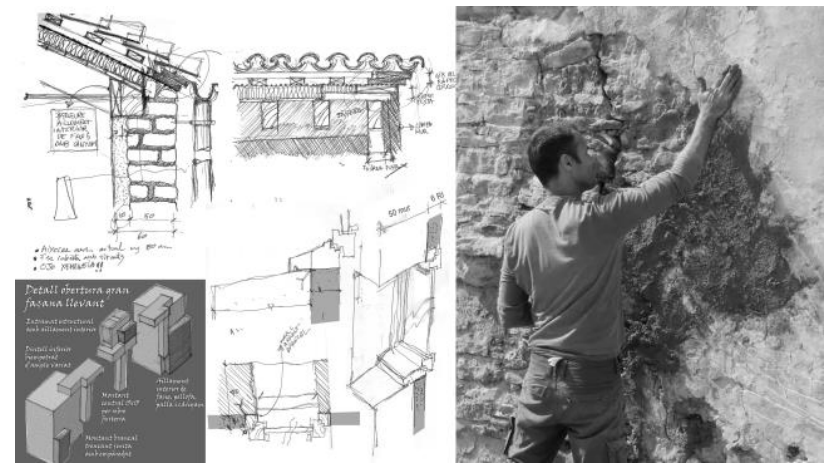

Figure 4. Design and applying process of the inside thermal layer.

2.3 Achieve optimal levels of daylight and natural ventilation without abandoning the traditional architectural language

The original masia didn't enjoy very high standards of natural light, having quite dark inner spaces. The masia was usually a square shape, with a big surface, so natural light didn't reach into the building core. They lacked availability for large glazed windows, and they were more concerned about keeping the place warm inside rather than having natural light comfort.

Actually, this feature was introduced by modern architecture. On the contrary, natural ventilation was not a problem in earlier days since the doors, windows, slabs and roofs were not airtight and air could quickly pass through.

Our client insisted on light, space and adequate ventilation. To achieve this, we created a central atrium that works as an open patio without breaking the general volume. Thanks to this peculiar solution, the outdoor perimeter doubled, and all the rooms could have cross ventilation and plenty of natural light. The generous inner space of the central porch delivers highquality light to the whole building. As the pioneering Catalan architect Josep Maria Sert (Arnús, 2019) said: natural light in our Mediterranean latitude has to come filtered through sophisticated mechanisms to assure proper visual comfort. Of course, this empty central core also helps to guarantee thermal comfort in the summer and facilitates the enjoyment of the great Eastern view from the West area (Figure 5).

This porch can be defined as an intermediate space, an architectural element that has always been used in our Mediterranean culture and that allows an optimal use of the environment and as Helena Coch (Coch, 2003) points out on her $\mathrm{PhD}$ : "The usefulness of useless spaces: a contribution to the assessment of environmental comfort in the architecture of intermediate spaces".
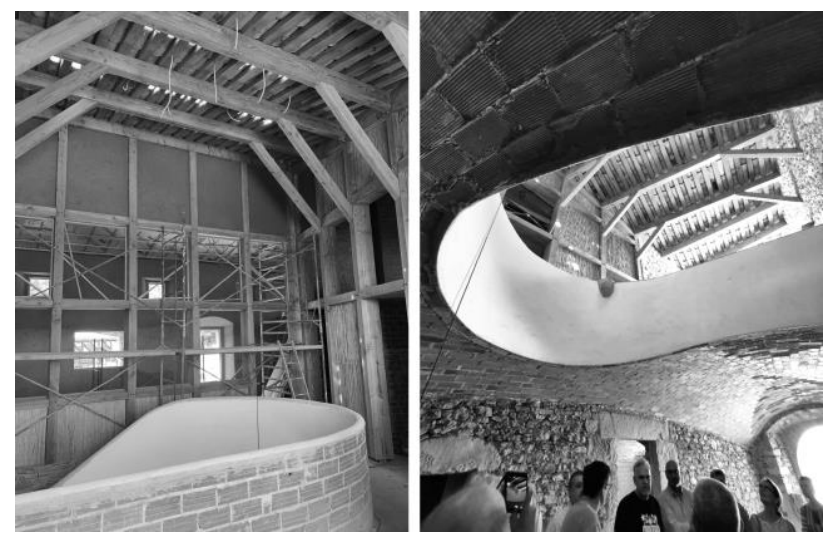

Figure 5. Natural light and ventilation provided by the central porch

\subsection{Architectural mechanisms to enjoy the views without excessive visual impacts.}

Enjoying the landscape views was valued between the monarchy of the XVII century and among the regular population at the end of the XIX century (Sanz, León, 1994).

Quite obviously masias never cared about big openings towards the best views around. Openings were strictly for functional purposes and, in some cases, as a distinctive sign on the main façade. Today's society has a strong attraction to excellent views, and this quality can make a difference in a rural hotel. It was not easy to open big windows in a traditional masia without causing an undesirable visual impact. As we usually do, we search for some kind of traditional elements that can be reinterpreted in a new building. In this case, we choose the big granary balcony usually made out of wood that serves to dry grain through natural ventilation but covered from the rain.

When setting those external references on the main facade, we use the natural stone slab as a cantilever and a solid wood slab covered with a zinc sheet as a roof. Thanks to the cantilever the big size balcony doesn't appear as obvious as a facade element and the general image of the facade becomes quite harmonious.

Of course, this very particular element is just a kind of prototype, and many other solutions can be created to fit big size openings on a traditional facade without excessive visual impact. We firmly believe that the use of pre-industrial materials is one of the ways to guarantee a proper contextualisation between new architectural requirements on traditional anonymous buildings (Figure 6). 


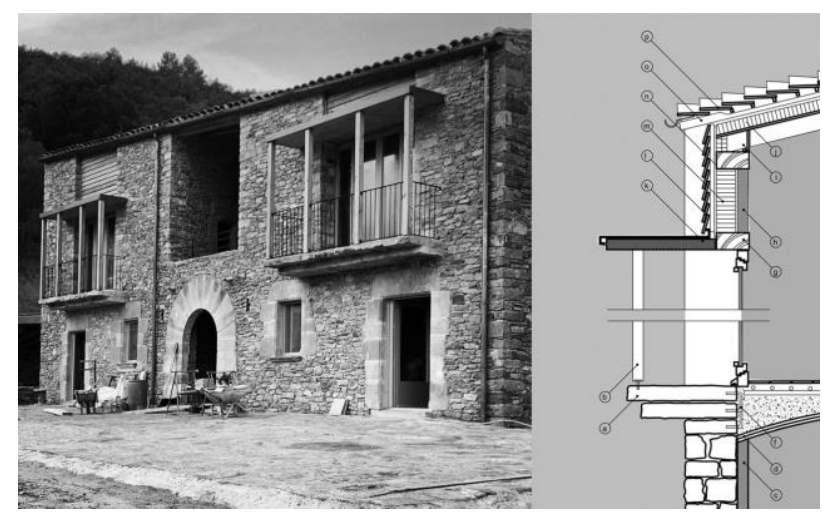

Figure 6 . The complexity to set big opening on a masia by using traditional architectural references and using exclusive pre industrial materials

2.5 Provide a certain contemporary aesthetics without abandoning the exclusive use of pre-industrial materials

To try to avoid the almost impossible dialogue between the so called modern architecture with the traditional one is the reason we always have to use traditional techniques when restoring anonymous pre-industrial buildings. That does not mean we restrict ourselves to rebuilding exactly the original building; we believe that today's building requires new aesthetics; comfort standards and the production system are different. Transforming a facade profoundly or expanding a building by using the same technique as the original one should be a guarantee for modernisation without architectural brutality.

As Léon Krier remembers: traditional architecture still represents a living language, although many architects have lost the will to learn his grammar and use his vocabulary (Krier, 2013).

We could add that, by the self-limitation of using preindustrial material and traditional techniques, this grammar and its vocabulary quickly returns.

Traditional materials can be classified into four broad groups. Natural stone and the aggregates, then earth and ceramics, then the traditional lime and plaster binders and finally organic materials such as wood and vegetal fibres. With those materials, humankind has developed any kind of architecture from its origins until 150 years ago.

On our project, we have added the $0 \mathrm{Km}$ self-limitation for ecological reasons, and the result can be defined in four points (Roselló, 2019):

2.5.1 Geological resources: The use of local stone, and especially of aggregates, guarantee an optimal contextualisation to the pre-existing anonymous buildings. This clash with the legal framework that regulates extractive activities; for this reason, the stones of the original site have been the only deposit available for the rehabilitation.

Besides the use of the original masia stone for rebuilding the new walls, we used the incredible slab stones that were laid there to create the main façade balcony cantilever and impressive outdoor pavement in front of the owners dwelling.
2.5.2 Earth and ceramic: As we explained earlier, we use earth (clay) coating for improving thermal properties for the new indoor spaces. We have applied this coating on to the inside of the central porch wooden facade. We have used a local made CEB (compressed earth block) for both structural walls and division ones.

Ceramic bricks have been traditionally used in the construction of Catalan vaults (Figure 8). This local building method has always been used in the masias of the province of Girona (Alcindor, 2018). We have used industrial tiles because they are lighter and much cheaper. This contemporary way of raising Catalan vaults has been mastered in the Spanish post-civil war, by the architect Bosch i Reig (Chamorro et al., 2012).

2.5.3 Traditional conglomerates: Truly local conglomerates are no longer available, given that the production centres have been reduced to a few manufacturers of lime or natural cement throughout Catalonia. In this case, it is essential to prescribe reasonably local conglomerates as support for local production that has survived to the present, such as Ponts de Molins, Llierca, Cervera, Guardiola de Berguedà, Olesa de Bonesvalls or Arboç. (Ramírez-Casas, 2018).

Hydraulic natural lime has been used as a foundation and structural walls binder; meanwhile, aerial lime is used for rendering inside walls. Natural cement has been used together with gypsum for Catalan vaulting, the first layer using gypsum and second, natural cement.

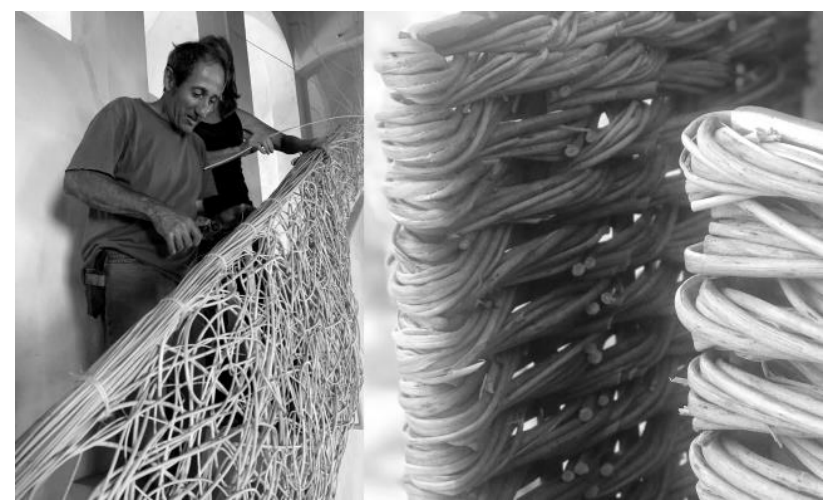

Figure 7. We have stimulate from the design the return of basketry in architectural site works

2.5.4 Massive wood and natural fibres: Before we had white poplar, cherry, red pine, yellow pine, boxwood, chestnut, acacia or oak for every construction need, now solid wood for construction has been reduced to two or three species, predominantly Scandinavian, Austrian or French.

Today, in Montseny, Catalonia, we have a producer who in the '50s planted Douglas pine and is now ready to offer us an optimum raw material quality just $95 \mathrm{~km}$ away from the worksite. In no such amount. Also, we have a smaller producer of chestnut just $20 \mathrm{~km}$ away (Figure 8).

Within this chapter, we have the exciting world of vegetal fibre weaving. In this case, the problem is not so much the availability as the technical capacity of manufacture (Figure 7). In each region, there are lattice traditions that have evolved into huge technical diversity. Wicker, palm leaf, straw, esparto grass, willow or chestnut, have been braided to make baskets, tools or panels that we can occasionally recover in the use of architectural construction (Kuoni, 2009). 


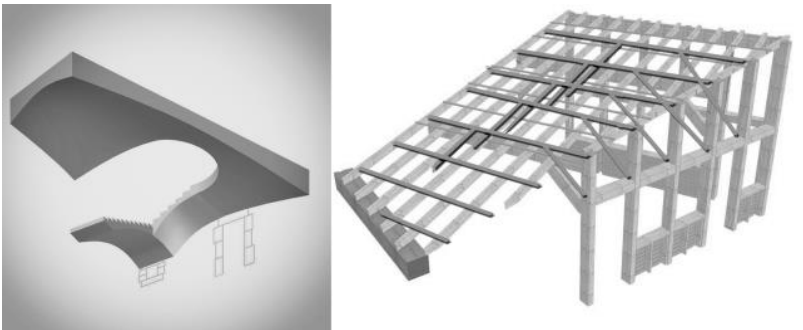

Figure 8. Using traditional techniques should not be a limitation in contemporary architectural language

\subsection{How to work and design as a team with contemporary} local artisans

As said before, when carrying out a permaculture project, the strict scientific concept is transferred. This project, from the beginning, covered the social and territorial scale of a transversal approach. At this point, the artisan's role takes significant importance. Before deciding what to do, we know in advance who will do it. We have been learning from local experts for many years that share our way of doing things. This mutual trust allows us to break with the typical hiring scheme.

First, we agree on the criteria, then the client requirements are studied and finally, the work is adjusted to the available budget. To the extent that there is teamwork from the initial stages, the work done by the craftsmen adds value and personalisation to the finished work

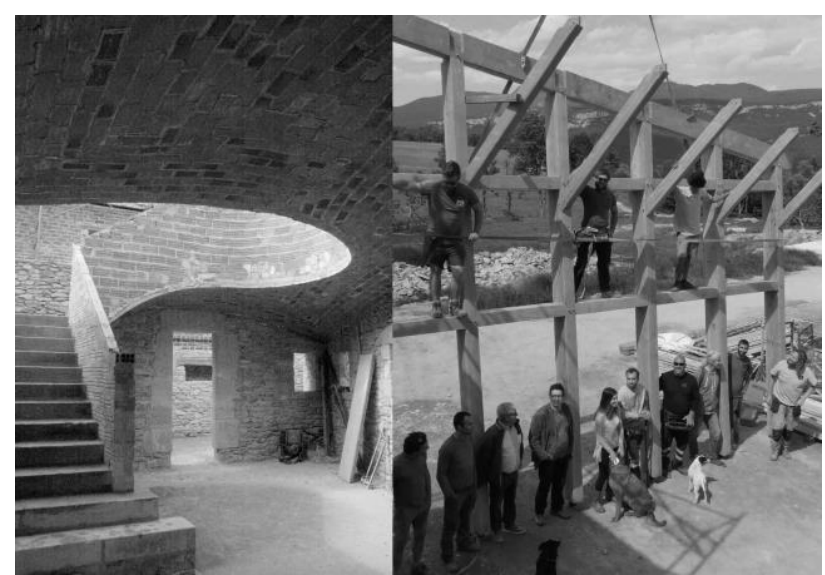

Figure 9. Catalan vaulting and massive wooden frame, two traditional techniques that allow the artisans to show theirs skills

As an architect, I must adjust the design to the skill of the artisans and not vice versa. Even, in some cases, certain constructive elements are defined to show the highest ability of the executor. With this way of designing architecture, the relation between theory and practice is articulated, and the success obtained is due to both agents.

As I pointed out ten years ago, from my point of view, the good vibes among the components of team work is a raw material in itself (Figures 9 and 10). This work philosophy was enhanced by the owner who, from the beginning, was involved in the dayto-day work and ended up part of the work team. (Rosello, 2008).

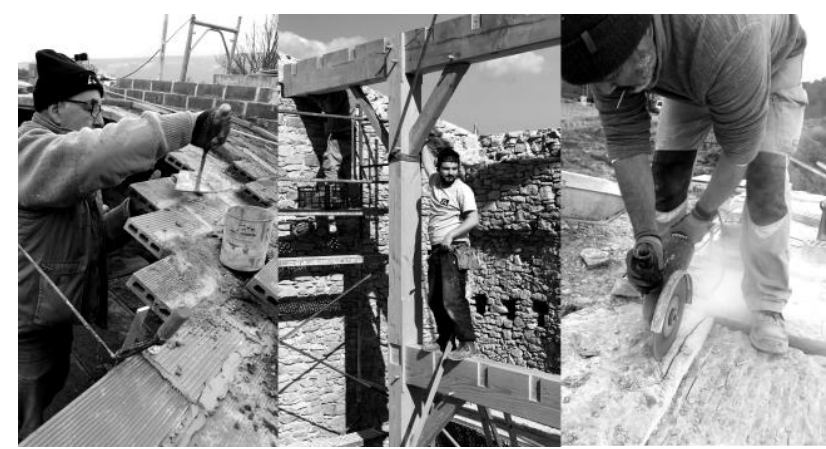

Figure 10. Little of the final result would have been possible without the shared authority with expert craftsmen

\section{CONCLUSIONS}

For many reasons, this peculiar project could be considered a prototype case. Both the owner and the architect agreed on using mainly local materials, to bring out the best of the artisans involved and use the extensive catalogue of traditional technologies from vernacular architecture.

At the same time, thanks to the advanced state of ruin of the original building and the design freedom that was given by the local administration, this project can be considered as an example of new construction. The boundaries between new and old or between modernity and tradition are diluted by the use of traditional techniques.

We can be assured that the use of traditional techniques seems to have a viable future. This optimistic vision is based on four current trends.

\subsection{Sustainable motivation}

Current projects have to deal with the prevailing variables of sustainability. One of the strategies for solving this challenge is rediscovery traditional techniques that, despite belonging to subsistence economies for millennia, can now teach lessons in today's postmodern society.

\subsection{Social motivation}

The transition from organic metabolism to industrial metabolism has led to a crisis of civilisation, which is not only ecological and economical but also social. The virtues of using traditional techniques go beyond the strict field of architecture, as they have positive consequences on a territorial, human and social scale. For example, the figure of the craftsman is instrumental in incorporating this traditional knowledge, and his role in the project process involves coordination with the architect.

\subsection{Aesthetic motivation}

More and more architects are critical of the formal solutions inherited from the icons of modernity. There is a demand for the recovery of fundamental architectural patterns, before modern architecture. For a timeless beauty that escapes the dizzying aesthetic fashions. Architects need to recover a lost syntax, to be able to compose constructions tailored to current formal requirements. 


\subsection{Professional motivation}

Amid a significant polarisation of the sector, the architect has mostly lost control of the production processes. Creativity is often reduced to the pre-project phase, while most of the technical definition and control of the work is going to external technical teams. Working with traditional techniques and artisans avoids this alienation from work. When the architect and artisans involved recover control of the production processes at the site, creativity becomes essential in all stages of the project. (Figure 11).
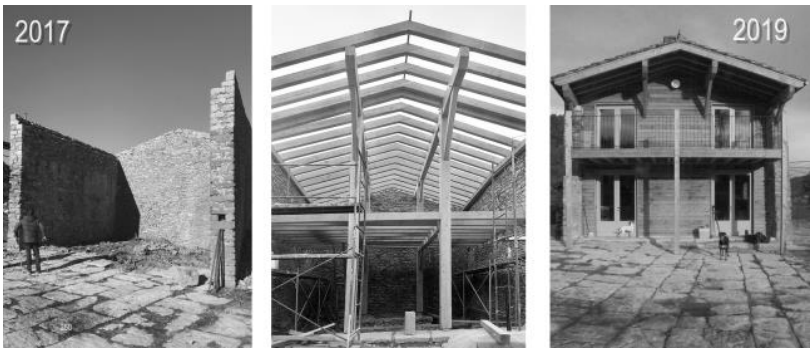

Figure 11. Evolution of the construction of the owner's house

\section{ACKNOWLEDGEMENTS}

There is a long list for showing the acknowledgements since this projects rally has been possible thanks to a significant team effort.

Gerard Bofill,, property owner and project promoter, had an evident ambition to build up an honest permaculture project and to transform his new life with the abandoned masia. $\mathrm{He}$ understood the uniqueness of this project, so he generously organized a barbecue every few months with the whole team.

Jordi Fornaguera, was the principal builder. I have worked with him for a long time, and he has shown me many lessons from local experience (Roselló, 2012). Albert Muñoz, his son in law, is taking over with a high ambition to apply new sustainable solutions.

Max Rutgers, Dutch Compagnon for carpentry. We met at the Mas Marroch project (Solanas, 2016). Since I knew him, the wooden structures became part of our architectural repertoire. He gets involved from the very beginning of the design process.

Jordi Doménech,is a Catalan vault expert from Montgat. He is a real genius in both building and designing. A very generous craftsman with whom collaboration is always a pleasure.

Carles Perez is a biologist specialising in depurating and filtering sewage systems and swimming pools. With him, the project completes the water cycle correctly. Renovating a Masia is indeed a landscaping matter.

Josep Llausà, is a local carpenter from Flaçà. They have been carpenters since the 17 th century. Today the company has managed to adapt to the complexity of the production system and restores many farmhouses in Girona.

Hamed Talib, engineer and Jordi Padrés, electrician and plumber, were in charge of design for the whole facility. As a premise, we avoid an excess of sophistication, and a system that was easy to manage directly by the owner was proposed.
Oriol Balliu, is an earth construction expert in cob, adobe, plasters and thermal coatings. I was lucky to be the architect of his house back in 2010. For this first cob house in Girona, we received the 2014 EcoViure first prize from Fira de Manresa (Alcindor, Roselló, 2012).

Josep Mercader and Magda Martinez, are both basketry craftsmen. They are an example of living the profession as a lifestyle. With them, any design is a possibility for a creative solution.

Matilde Londner, is a water management expert. She was responsible for the management of drinking water, rain collection and purification.

Francesc "Xicu" Oliveras, is the mayor of Sant Aniol de Fonestres. From the very beginning, he gave his support to the project and facilitated all the procedures of the local administration. He provided much oral information about the history of Can Buch.

Fede Igarzabal, is the Argentine cook. He has already begun to transform the landscape into gastronomy. With precision and tenacity, he creates incredible menus that illustrate the virtues of this fantastic life project.

Kim Arcas, architect. We both studied at the same school ETSAV and belonged to the same research group call OASI. He encouraged the owner to contact me for the rehabilitation project; without him, nothing of this would have happened.

\section{REFERENCES}

Alcindor M., 2018 Allò que amaga cada decisió. Les decisions constructives en les intervencions sobre l'arquitectura tradicional Construint el territori, Arquitectura tradicional I paisatge de Catalunya, catàleg de l'exposició a cura de Fabien Van Geert I Ferran Estrada Bonell Departament de Cultura de La Generalitat de Catalunya

Alcindor, M., Roselló, O. 2013 Harmonic diachrony: current use of traditional techniques in rehabilitation projects. International Conference on Vernacular Architecture CIAV2013 | $7^{\circ}$ ATP | VerSus

Alcindor M. Roselló O., 2012 Cob una técnica accesible para auto constructores novatos. Restapia UPV

Arnús, MdM., 2019 Ser(t) Arquitecto. Anagrama biblioteca de la memoria 978-84-339-0812-4

Chamorro M.A, Garcia, B., Salvat, J., 2012 La construcción de la bóveda tabicad en el Hotel Cap Sasal de Begur. Articulo presentado en el Congreso Internacional "Domes in the World" celebrado en Florencia del 19 al 23 de marzo del 2012

Coch, H., 2003 La utilitat dels espais inútils : una aportació a l'avaluació del confort ambiental a l'arquitectura dels espais intermedis. Tesis doctoral dirigida por Rafael Serra Universitat Politècnica de Catalunya Departament de Construccions Arquitectòniques I

Holmgren, D., 2007 La esencia de la permacultura. Holmgren design services 
Krier L., 2012 La arquitectura de la Comunidad, la modernidad tradicional y la ecología del urbanismo. Documentos de Composición Arquitectónica Editorial Reverté. Barcelona (page 261)

Kuoni, B., 2009 Cesteria tradicional ibérica Ediciones Del Aguazul, S.L.

Prieto, E., 2019 Historia medioambiental de la Arquitectura Grandes temas Cátedra

Ramírez-Casas, J. 2018 Ciment natural a Catalunya : història, producció i usos Rosell, J.R., Rosell, J., Comunicación de congreso Fecha de publicación2018 EditorEscola Politècnica Superior d'Edificació de Barcelona

Roselló, O., 2019 Can Buch o la rehabilitació Km 0 com a estratègia tradicional contemporània. Jornada tècnica, prèvia al segon Congrés Masia-Territori. Dossiers Agraris ICEA

Roselló , O., 2012 Evolución, presente y experiencia con la bovada tabicada "Aprenent de la volta catalana" Jornades Tècniques a la UdG 10, 11 i 12 de maig 2012

Roselló, O., 2008 Creation de lodgements privés dans un quartier en pleine transformation. Rehabilitation de trois batiments dans la rue Carders, Barcelone. Expériences de rehabilitation méditerranéennes RehabiMed (page 158)

Sanz M.V, León F.J 1994 Estética y teoría de la arquitectura en los tratados españoles del siglo XVIII Consejo Superior de Investigaciones Científicas Madrid (page 1252)

Solanas, T., 2016 El Ágora de l'espai Mas Marroch Revista EcoHabitar Proyecto Bio

Tello, E., 2010 Vint i cinc idees i algunes propostes per a una nova cultura del territori. Conferència inaugural, La Resclosa, Núm. 13, p. 9-18

\section{NOTES}

All figures and images come from Oriol, Roselló archive. 